\title{
Sulfonated hypercrosslinked adsorbent - synthesis and application in analytical chemistry
}

\author{
- Huynh Minh Chau \\ - Pham Thi Thuy Dung \\ - Do Quang Khoa \\ - Nguyen Anh Mai \\ University of Science, VNU-HCM \\ (Manuscript received on March 20 $0^{\text {th }} 2013$, accepted on September $10^{\text {th }} 2013$ )
}

\begin{abstract}
Chromatographic technique becomes surface. In this study chlorosulfonic acid was more and more popular in analytical chemistry thanks to the diversity of stationary phases. Among the materials hypercrosslinked poly(styrene-codivinylbenzene-co-vinylbenzyl chloride) is of great interest because of its exceptional high surface area and chemical resistance. Despite the advantages the polymer, its applications are still limited. Its surface is too hydrophobic for hydrophilic analytes therefore several reactions have been used to modify this material. The most popular reaction is sulfonation in which sulfonate group is introduced on to the material used as sulfonation reagent, the resulting polymer has two functional groups: sulfonate and sulfonyl chloride. Then sulfonyl chloride group was hydrolyzed by sodium hydroxide to form sulfonate group. The reaction conditions namely ratios of reagent to polymer and reaction time were investigated for high cation exchange capacity. The home-made sulfonated material was sucessfully used as solid phase extraction (SPE) sorbent with high static capacity (10 meqv/g), dynamic capacity (3.8 meqv/g), fast mass transfer, and high enrichment factor.
\end{abstract}

Key words: hypercrosslinked polymer, sulfonation, chlorosulfonic acid, absorbent, poly(styrene-co-divinylbenzene-co-vinylbenzyl chloride)...

\section{INTRODUCTION}

Sulfonated poly(styren-divinylbenzene) has been widely used as cation exchanger [1]. The degree of crosslinking of the material can be further enhanced by incorporating vinylbenzyl chloride to the polymer and performing an extra crosslinking step using $\mathrm{FeCl}_{3}$ as catalyst. The polymer which is referred to as hypercrosslinked polymer possesses very high specific surface area, resulting in high capacity after modification $[2,3]$. In this work the sulfonation process were

studied to prepare cation exchanger with high capacity and fast mass transfer.

\section{MATERIALS AND METHODS}

Materials and equipments

Styrene (STY), dodecanol, toluene, benzoylperoxide and 1,2 dichloromethane were purchased from Merck. Divinylbenzene (DVB), vinylbenzyl chloride (VBC), chlorosulfonic acid were products of Sigma Aldrich. Methanol, nitric acid and lead nitrate were of analytical grade

Trang 32 
(China). Inhibitors in the monomers were removed by $0.5 \% \quad \mathrm{NaOH}$ solution. A spectrophotometer MC V325-XS was used for spectrophotometric determination of $\mathrm{Pb}^{2+}$.

\section{Preparation a hypercorsslinked material}

To obtain a polymeric support with suitable surface area $\left(\sim 200 \mathrm{~m}^{2} / \mathrm{g}\right)$ for SPE applications the synthesis procedure was optimized in a previous study [4]. The inhibitor-free monomers $(2.10 \mathrm{~g}$ STY, $1.20 \mathrm{~g} \mathrm{DVB}$ and $0.70 \mathrm{~g} \mathrm{VBC}$ ) were mixed well with porogen solvents $(1.90 \mathrm{~g}$ toluene and $4.10 \mathrm{~g}$ dodecanol) by sonication for $5 \mathrm{~min}$ before $0.84 \mathrm{~g}$. benzoyl peroxide was added to the mixture. The polymerization was performed at $80^{\circ} \mathrm{C}$ for $24 \mathrm{~h}$. The resulting polymer was cut into small pieces, residual monomers and solvents were then removed by Shoxlet extraction with methanol for $24 \mathrm{~h}$ and dried at $60^{\circ} \mathrm{C}$ for $6 \mathrm{~h}$. The dried material was then crushed and sieved to obtain particle size of $45-105 \mu \mathrm{m} .1 .7 \mathrm{~g}$ polymeric particles was swollen in $20 \mathrm{~mL}$ of 1,2dichloroethane for $2 \mathrm{~h}$ and cooled in an ice bath before adding $0.50 \mathrm{~g}$ the Lewis acid catalyst $\mathrm{FeCl}_{3}$. The mixture was stirred to disperse well the catalyst and allowed to reach room temperature. The hypercrosslinking process was conducted at $80^{\circ} \mathrm{C}$ for $24 \mathrm{~h}$. The product was washed subsequently with methanol, $0.5 \mathrm{~mol} / \mathrm{L}$ $\mathrm{HCl}$ in acetone, and methanol followed by drying at $60^{\circ} \mathrm{C}$ overnight.

\section{Sulfonation procedure}

$1.65 \mathrm{~g}$ the hypercrosslinked material was swollen in $28 \mathrm{~mL} \mathrm{1,2-dichloroethane} \mathrm{for} 2 \mathrm{~h}$, to which $28 \mathrm{~mL}$ chlorosulfonic acid was added, and the sulfonation reaction was carried out at room temperature. The product was washed with distilled water, hydrolyzed with $1 \mathrm{M} \mathrm{NaOH}$ at $100^{\circ} \mathrm{C}$ for $30 \mathrm{~min}$. The base was removed by washing with $2 \mathrm{M} \mathrm{HNO}$, and finally with distilled water to neutral and dried at $60^{\circ} \mathrm{C}$ overnight.

\section{Determination of ion-exchange capacity}

Ion $\mathrm{Pb}^{2+}$ was used as a model cation to evaluate the capacity of the products. The concentration of $\mathrm{Pb}^{2+}$ in eluents was determined based on the absorption of the complex of $\mathrm{Pb}^{2+}$ with xylenol orange in aqueous phase at $578 \mathrm{~nm}$. The static capacity was determined by the measurement of $\mathrm{Pb}^{2+}$ in aqueous solution before and after getting into contact with the adsorbent for $24 \mathrm{~h}$ with the aid of a shaking machine. While in the experiments for dynamic capacity $\mathrm{Pb}^{2+}$ solution was passed through the SPE cartridge filled with $0.1 \mathrm{~g}$ adsorbents using a peristatic pump at flow rate of $1 \mathrm{~mL} / \mathrm{min}$.

\section{RESULTS AND DISCUSSION}

Preparation of sulfonated hypercorsslinked material

Effects of reaction time and sulfonation reagent level on the ion-exchange capacity

The sulfonation efficiency, represented as the capacity of the resulting ion exchanger, was studied under various conditions. 

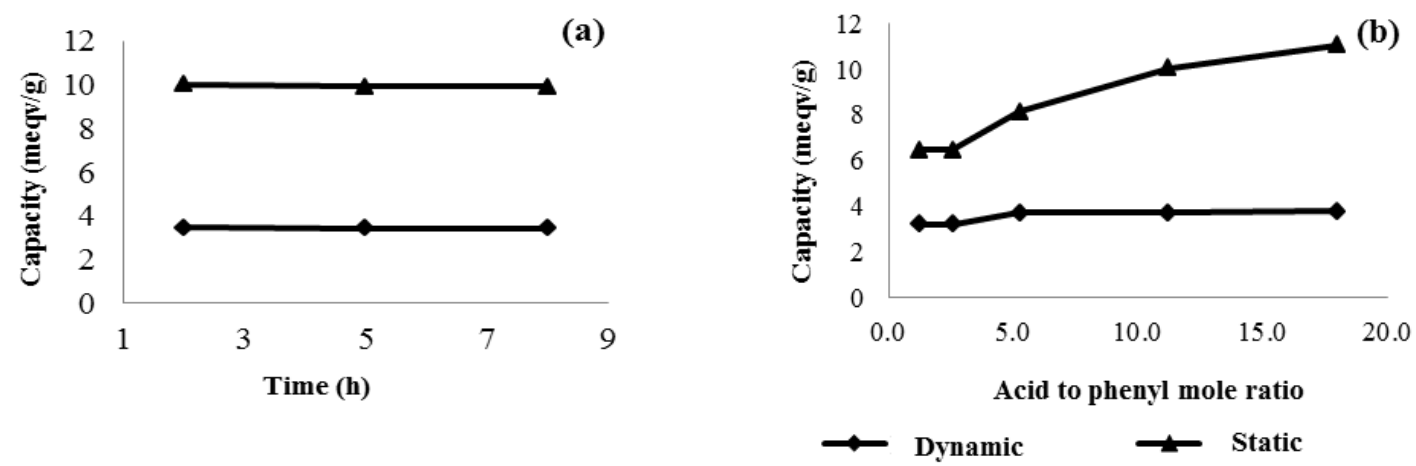

Fig. 1. Influence of reaction time and sulfonation reagent level on the ion-exchange capacity

Firstly, the reaction time was varied from 2 to $8 \mathrm{~h}$ at the room temperature with the mole ratio of the sulfonating reagent (chlorosulfonic acid) to the phenyl group of 11 . It was found that the reaction rate is rather high resulting in similar capacity in the investigation time range (Fig.1a). The static and dynamic capacities were of 10.0 and $3.8 \mathrm{meqv} / \mathrm{g}$, respectively. These findings were in accordance with the known mechanism of the reaction which has two steps. In the first step chlorosulfonic acid quickly reacts with the phenyl rings to form sulfonic group; in the second step sulfonic group is slowly converted to sulfonyl chloride by reaction with the excess chlorosulfonic acid [5,6]. The longer reaction time, the more sulfonyl chloride group is. After hydrolysis with $\mathrm{NaOH}$, sulfonyl chloride is converted to sulfonic; therefore, it is useless to use too much sulfonating reagent unless sulfonyl chloride is required for further modification. The optimal ratio of chlorosulfonic acid to phenyl group was of $\sim 5$.

Secondly, the mole ratio of chlorosulfonic acid to phenyl group was varied in the range of 1,3- 18 while the reaction was conducted for $2 \mathrm{~h}$. A dramatical increase in the static capacity from 6.5 to $11 \mathrm{meqv} / \mathrm{g}$ while the chlorosulfonic acid did not show significant effects on the dynamic capacity (Fig.1b). The higher level of reagent, the more chance it can access the surface of the material in tiny pores, this resulted in the higher static capacity but un-affected the dynamic when the cation continuously passing through the adsorbent and therefore, had too less time too get into the tiny pores. It should be kept in mind the dynamic capacity is of far more importance than the static one in SPE applications.

\section{Characterization the sulfonated adsorbent}

Investigation of the specific surface area by BET: there was a dramatical decrease in specific surface area when the reaction proceeds for long time. In fact, it decreased from $29.7 \mathrm{~m}^{2} / \mathrm{g}$ for $2 \mathrm{~h}$ to $17.7 \mathrm{~m}^{2} / \mathrm{g}$ for $8 \mathrm{~h}$. Therefore, the reaction time of $\sim 2 \mathrm{~h}$ is a good choice this this case in terms of time and surface area. A decrease of surface area was probably due to agglomeration of some isolated copolymer nuclei (cauliflower form) during the sulfonation.

The chemistry of the intermediate materials and the final products were confirmed by FTIR

- The un-modifed material was characterized by BET, FTIR and aromatic compound adsorption capacity. The spectrum a) in Fig. 2 shows a strong peak at $699 \mathrm{~cm}^{-1}$ and 542 $\mathrm{cm}^{-1}$ which can be attributed to the C-Cl stretching band. The adsorptions observed around $1369 \mathrm{~cm}^{-1}$ to $1600 \mathrm{~cm}^{-1}$ indicate the existence of phenyl group and $800 \mathrm{~cm}^{-1}$ to $900 \mathrm{~cm}^{-1}$ due to a benzene ring with orthopositioned functional groups. The results denote the product prepared were copolymer of STY-DVB-VBC. With BET measurement its specific surface area was of

\section{Trang 34}


$228 \mathrm{~m}^{2} / \mathrm{g}$ and $1 \mathrm{~g}$ material was able to adsorb 90mg phenol. With these characteristics the hypercrosslinked material can be used as support of stationary phases for SPE.

- The IR spectrum of the sulfonated material had adsorption bands of phenyl group as those of the starting material. In addition, strong adsorption at $1370 \mathrm{~cm}^{-1}$ and around
$760 \mathrm{~cm}^{-1}$ to $1033 \mathrm{~cm}^{-1}$ can be due to $\mathrm{S}=\mathrm{O}$ and $\mathrm{S}-\mathrm{O}$ stretching bands, respectively. However, the spectrum c) in Fig. 2 shows a strong peak at $1172 \mathrm{~cm}^{-1}$ which is attributed to the $\mathrm{S}-\mathrm{Cl}$ stretching band, which disappears after the hydrolysis by $\mathrm{NaOH}$ (Fig. 2b) this indicates that all of sulfonyl chloride groups were converted to sulfonated group.

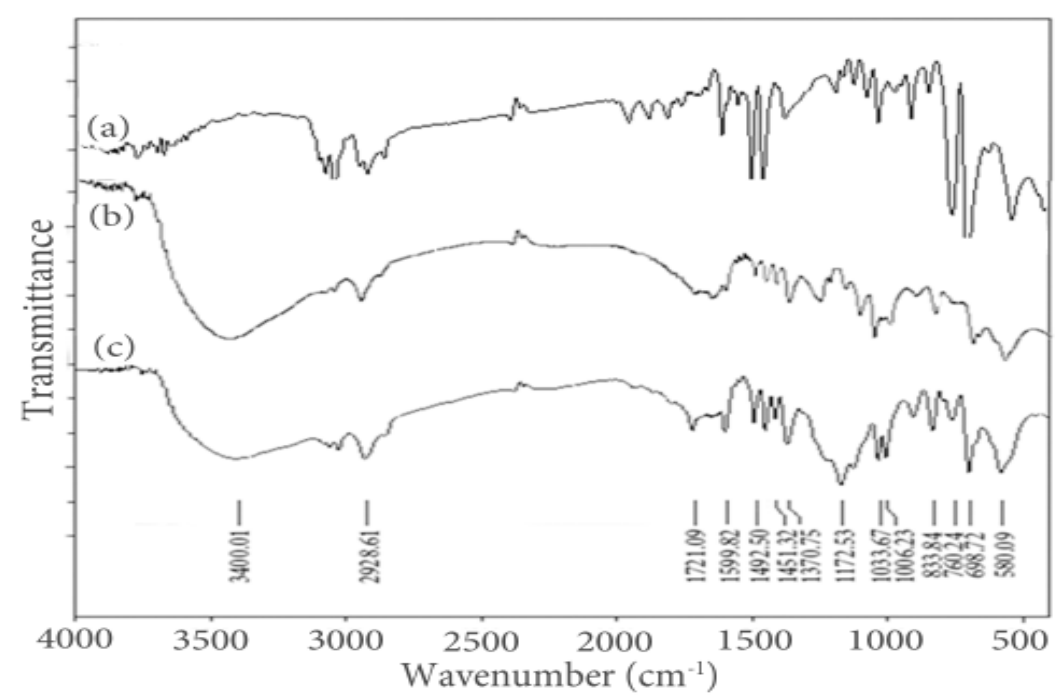

Fig. 2. An IR spectrum of (a) starting material, (b) sulfonated material after and (c) before hydrolysis

Evaluation of the adsorption properties of the sulfonated hypercrosslinked material

Dynamic capacity and the kinetics of the adsorption process

To use as adsorbent for SPE both dynamic capacity and the kinetics of the process are of great concern. These properties can be revealed studying the breakthrough curves. Polypropylene cartridges were filled with $0,1 \mathrm{~g}$ of the adsorbent. The material was washed with $10 \mathrm{~mL} 2 \mathrm{M} \mathrm{HNO}_{3}$, followed by double-distilled water until neutral. A $250 \mathrm{ppm} \mathrm{Pb}^{2+}$ solution was loaded at a flow rate of $1,5 \mathrm{~mL} / \mathrm{min}$ and $\mathrm{Pb}^{2+}$ concentration in each $4 \mathrm{~mL}$-portion the eluent was determined by spectrophotometric method. The breakthrough curve of $\mathrm{Pb}^{2+}$ was constructed based on the experimental data (Fig. 3a). The breakthrough curves of three SPE cartridges filled with the same material show that the metal ion in the first $30 \mathrm{~mL}$ was very efficiently "caught" by the adsorbent at flow rate of $1,5 \mathrm{~mL} / \mathrm{min}$. As can be seen in Figure $1.5 \mathrm{~b}$ more than $94 \%$ of the adsorbed ion can be recovered using only $6 \mathrm{~mL}$ $\mathrm{HNO}_{3} 2 \mathrm{M}$ making it is possible to obtain an enrichment factor up to more than 300 (the initial volume of sample of $2000 \mathrm{~mL}$ ) (Fig. 3b). 

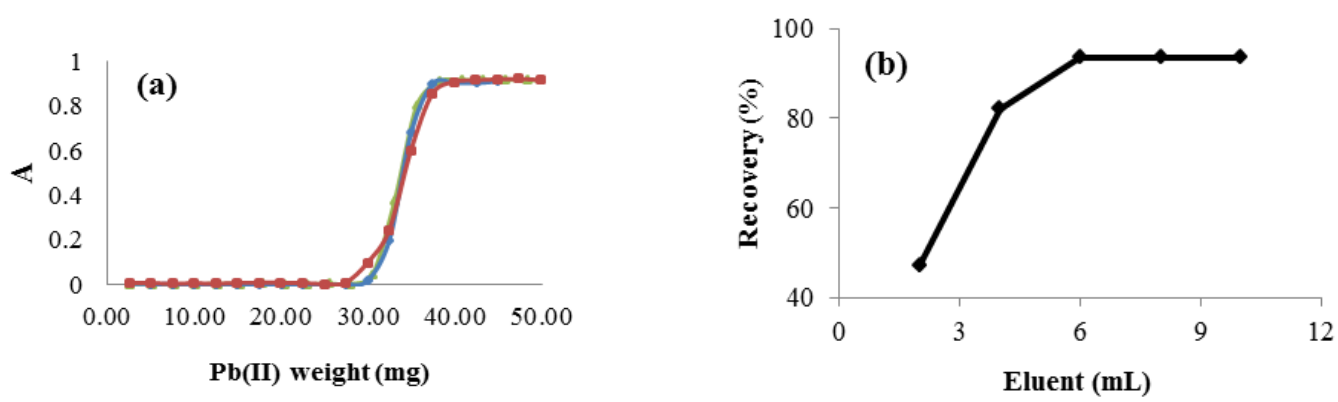

Fig. 3. (a) Breakthrough curve of $\mathrm{Pb}^{2+}$ and (b) and elution profile of $\mathrm{Pb}^{2+}$ with $\mathrm{HNO}_{3} 2 \mathrm{M}$

Effect of initial concentration of $\mathrm{Pb}^{2+}$ on the recovery

This part of the study is to investigate the ability of quantitative adsorption and desorption of the sulfonated material in real samples whose concentrations of ions can be vastly varied. Several $\mathrm{Pb}^{2+}$ solutions with concentration of 0,01 - $100 \mathrm{ppm}$ were loaded onto the SPE cartridges containing $0,1 \mathrm{~g}$ the sulfonated material and eluted by $6 \mathrm{~mL} 2 \mathrm{M} \mathrm{HNO}_{3}$. 5 replicates were done for each concentration. The results indicated that the recoveries ranged from $92 \%$ to $110 \%$ and RSDs were $16.9 \%$ and $3.8 \%$ for 0.01 and 100 ppm concentration, respectively (Fig. 4).

\section{The stability of the adsorbent}

The stability of ion exchangers after elution with strong acids allow their reuse for economic reasons. An SPE cartridge containing $0.1 \mathrm{~g}$ material was loaded with $50 \mathrm{ppm}^{2+}$ solution; the loading and elution procedure was repeated 5 times. The mean recovery was of $101 \pm 5 \%$ indicating the high chemically stability of the adsorbent.

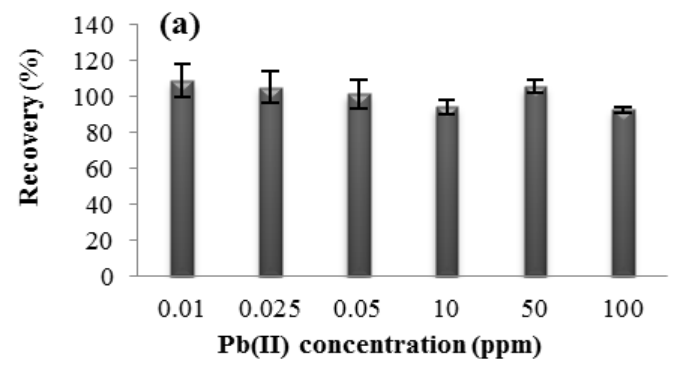

Fig. 4. The recovery at different levels of $\mathrm{Pb}^{2+}$

\section{CONCLUSION}

The sulfonated material was successfully synthesized with high capacity and fast mass transfer. The dynamic capacity of the adsorbent is of $3.8 \mathrm{meqv} / \mathrm{g}$ which is higher than other commercial products namely Bond Elut Plexa PCX, Oasis MCX, Strata X-C, SampliQ SCX. 


\section{Tổng hợp và ứng dụng vật liệu sulfonate siêu khâu mạng trong hóa phân tích}

- Huỳnh Minh Châu

- Phạm Thị Thùy Dung

- Đỗ Quang Khoa

- Nguyễn Ánh Mai

Trường Đại học Khoa học Tự nhiên, ĐHQG-HCM

\section{TÓM TÁ́T}

Kỹ thuật sắc ký ngày càng phát triển mạnh mẽ trong lĩnh vực phân tích nhờ vào sụ̣ đa dạng của các loại pha tĩnh. Trong số đó thì vật liệu siêu khâu mạng poly(styreneco-divinylbenzene-co-vinylbenzyl chloride) có vị trí quan trọng nhờ diện tích bề mặt lớn và khả năng kháng được hóa chất. Mặc dù có nhiều đặc điểm ưu việt, nhưng ứng dụng của vật liệu này vẫn còn hạn chế. Điều này là do vật liệu có bề mặt rất ky nước nên khó hấp phụ các chất ưa nước, vì vậy một số phản ứng đã được ứng dụng để biến tính bề mặt vật liệu. Trong đó thông dụng nhất là phản ứng sulfonate hóa nhằm đưa lên bề mặt vật liệu các nhóm sulfonate. Acid chlorosulfonic được sử dụng làm tác chất cho phản ứng nên sản phẩm có hai nhóm chức trên bề mặt: sulfonate và sulfonyl chloride. Sau đó nhóm sulfonyl chloride được thủy phân trong môi trường base để chuyển hóa thành nhóm sulfonate. Các điều kiện phản ứng như thỉ lệ tác chất so chất nền polymer, thời gian phản ứng được khảo sát nhằm thu được sản phẩm có dung lượng cao. Vật liệu sulfonate siêu khâu mạng tự tổng hợp được ứng dụng làm pha tĩnh cho cột chiết SPE với dung lượng tĩnh (10.0 eqv/g) và động (3.8 meqv/g) cao, tốc độ cân bằng cột nhanh và hệ số làm giàu mẫu lớn.

Từ khoá: polymer siêu khâu mạng, sulfonate hóa, acid chlorosulfonic, chất hấp phụ.

\section{REFERENCES}

[1] B. Saha, M. Strent, Adsorption of Trace Heavy Metals: Application of Surface Complexation Theory to a Macroporous Polymer and a Weakly Acidic Ion-Exchange Resin, Ind. Eng. Chem. Res., 44, 8671-8681 (2005).

[2] M.P. Tsyurupa, V.A. Davankov, Hypercrosslinked polymers: basic principle of preparing the new class of polymeric materials, Reactive and Functional Polymers, 53, 193203 (2002).
[3] J. Urban, F. Svec, J.M. Frechet, Hypercrosslinking: new approach to porous polymer monolithic capillary columns with large surface area for the highly efficient separation of small molecules, Journal of Chromatography A, 1217, 8212-8221 (2010).

[4] Hypercrosslinked poly(styrene-codivinylbenzene-co-vinylbenzyl chloride) synthesis and application in analytical chemistry, the poster in The $8^{\text {th }}$ Scientific Conference - University of Science. 
[5] I. Rabia, J. Zerouk, M. Kerkouche, M. [6] M. Bacquet, M. Salunkhe, C. Caze, Influence Belkhodja, Chemical and textural characte ristics of porous styrene-divinylbenzene of Chlorosulfonation on Textural and copolymers as a function of chlorosulfonation Chemical Parameters of StyreneDivinylbenzene Porous Copolymers, Reactive reaction parameters, Reactive \& Functional Polymers, 28, 279-285 (1996). Polymers, 16, 61-69 (1991). 